\title{
Un juicio de Paul Hazard sobre nuestra Revista
}

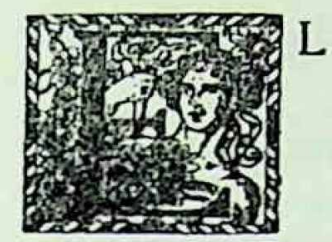

$L$ profesor francés $M$. Paul Hazard, que ha sido nuestro huésped, tuvo ocasión de leer los primeros números de ATENEA.

El distinguido catedrático ha querido expresar el juicio, ciertamente bastante benévolo. que le merece nuestra publicación. y en carta dirigida a nuestro representante en Santiago, don Roberto Meza, expone resumidamente su opinión y nos sugiere interesantes ideas sobre la labor que aun queda por realizar a ATENEA.

Como de hombre que entiende la materia, el juicio del señor Hazard, en lo que se refiere a las nuevas perspectivas de trabajo para la Revista de la Universidad de Concepción. es de gran interés. y por cierto las normas trazadas por el ilustre catedrático francés serán puestas por obra a medida que nuestra revista vaya afirmando y completando lo que él llama su spersonalidad vivientes.

La carta de $M$. Paul Hazard, traducida, es ésta:

-Santiago de Chile, 21 de Junio de 1924.

Mi querido amigo:

He examinado con vivo interés y con toda la atención que merecen, los tres primeros números de la Revista ATENEA, publicada por la Universidad de Concepción.

Muy bien ideada me parece esta revista. Tiene la cualidad, puesto que veo. al pie de los artículos. los nombres más estimados de las letras y de la política. Tiene la variedad: mezcla en las proporciones más justas, la poesía, la crítica. la economia política. las cuestiones sociales. Está lejos de olvidar la vida universitaria, pues recuerda su origen y cuida del papel que la Universidad debe desempeñar en la vida intelectual y moral de la nación.

¿Permitiría Ud. a un hombre que ha escrito mucho en las revistas, y que él mismo dirige la Revista de literatura comparada, sugerirle una idea? Talvez unas crónicas regulares, a cargo de hombres eminentes, atraerian vivamente la curiosidad de los lectores. Asi es como la Revista de Ambos Mundos ha visto aumentar considerablemente el número de sus subscriptores, desde el día en que a $M$. Poincaré le fué confiada la crónica política. ¿Crónicas, srevistas del mes», en todos los órdenes de la actividad nacional, provocan la atención, la discusión. y a menudo consiguen intensificar la vida de una revista, que debe ser ella misma como una viviente personalidad.

Hé aqui. rápidamente bosquejada, la impresión que entrego a la consideración suya. Pero no es sino la impresión de un extranjero, que no podría comprender las cosas desde el punto de vista del país, que es lo esencial. Quiera ver en ella solamente, mi querido amigo. una prueba de la estimación que siento por la Revista y por Ud.-P. Hazard. 